\title{
Current Trends in the Development of the Modern International Political System
}

\author{
Amiantov Alexey A. ${ }^{1}$, Amiantova Irina S. ${ }^{1} \&$ Novikova Anastasia V. ${ }^{1}$ \\ ${ }^{1}$ RUDN University, Russia \\ Correspondence: Amiantova Irina S., RUDN University, Russia. E-mail: politnayka@mail.ru
}

Received: January 20, 2020

Accepted: February 21, $2020 \quad$ Online Published: May 20, 2020

doi:10.5539/jpl.v13n2p63

URL: https://doi.org/10.5539/jpl.v13n2p63

The article is prepared within the support of the «RUDN University Program 5-100».

\begin{abstract}
The article describes various aspects of development dynamics of the international political system in the XXI century. The aim of the work is to determine the current state of the structure of the international political system and to assess the prospects for its further development. The article analyses general regularities of development of the structure of the international political system. The author concludes that the present structure of the international political system is gradually transforming. Its basic elements are eclectic because the process of transformation is uneven and incomplete. Moreover, the nature of relations between the main actors undergoes fundamental changes. The global arena tends to experience a heating confrontation against the background of increased ties within clusters of regional and macroregional actors.
\end{abstract}

Keywords: international relations, structure, international political system, state

\section{Introduction}

The structure of the system of international relations has always remained one of the paradigms for political science. Without understanding its basics and the development trends, it is impossible to interpret the current situation or predict the development of fixed processes in years ahead.

The study is significant due to the presence of major gaps in the degree of this research area. Recent empirical evidence is subject to reflection predominantly in the context of studying the cases of specific institutions and international organizations. Here we can cite studies of A.V. Valuev (Valuev, 2016), O.I. Ivonina (Ivonina, 2017), M.V. Ilyin (Ilyin, 2012), M.A. Kaverin and S.Yu. Malkov (Kaverin, \& Malkov, 2014). Conceptual studies on the stated topic (despite the evident value and significance) are often built on the basis of a normative approach: experts combine the analysis of the situation with the description of how it should develop from the standpoint of a certain system of values or an ideal model (Kovalev, 2017; Lantsov, 2018; Radyukova, Kulik \& Pakhomov, 2015; Revizorski, 2015). Many valuable publications that set the general direction for the topic research are based on the outdated empirical material. Given this, there is a need to update the results that were stated in those researches (Pantin \& Lapkin,2002; Ramonova, 2011).

\section{Research Methodology}

The methodology is built on a combination of structural, descriptive and comparative varieties of analysis. While writing this article, the authors used also traditional scientific methods: analysis, synthesis, comparison. The selected methods turn out to be helpful in reaching the research goal.

The aim of the study is to assess the current state of the structure of the international political system and the prospects for its further development.

\section{Findings and Discussion}

\subsection{The Transformation of the Structure of the International System: Concepts and Actors}

Addressing the transformation of the structure of the international system, first we should mention that there is no consensus within the scientific and expert community regarding what actor is its basic component. A number of political scientists, inter alia, share the point of view of K. Deutsch, singling out the nation in this capacity. 
Meanwhile, many experts agree with F.M. Burlatsky, who assessed the state as a key component of the international system. From another perspective suggests that in recent decades traditional international relations have transitioned to world politics, in which both state and non-state actors act as equal subjects. (among the pioneers of this approach were R. Keohane and J. Nye) (Melvil, 2004).

The reasoning of each of the concepts described above is sufficiently extensive. At the same time, none of the relevant explanatory models cannot fully describe the current political process. Particularly, the "state" approach proposed by F.M. Burlatsky cannot be used to assess processes involving cross-border actors - elite or ethnic groups, transcontinental corporations, religious movements, etc. The K. Deutsch "national" approach is applicable only when referring to people compactly living within the state, or to those "scattered" but consolidated, often in closed ethnic groups, capable to counteract assimilation of an external environment. The concept of "civil nation" hampers the practical application of the K. Deutsch approach. From this perspective, for instance, Arabs and the Negroid representatives of the Sudan, Macedonians and Albanians, Northern Irish protestants-orangists and Catholics of Ulster constitute a single actor. The last decades have demonstrated the instability of the civil nations that emerged in the XIX - XX centuries. It is not only about the dissolution of the unified Soviet identity and the subsequent collapse of the USSR. In Western Europe, serious problems with the integration of immigrants from Africa and Asia into local communities were already observed in the 1990s-2000s, and the migration crisis of 2015 finally led to a powerful surge of xenophobia within each of the parties involved in the conflict (Mosyakov, 2006).

At first glance, the concept of world politics suggested by R. Keohane and J. Nye is best suited to describe the present international system. However, the fact that its inherent division of the participants in the system of international relations is largely conditional needs to be addressed. The relationships between state and non-state actors often become so close that they cannot be considered as independent subjects. It does not concern only integration between the state and conditionally "national" financial and industrial groups. Thus, the Muslim Brotherhood (also known as Ikhwan) units that exist in many Middle Eastern countries are closely linked to the elites of Qatar, while the majority of equally numerous and influential Salafist movements are under the control of Saudi Arabia. However, the existing rigid vertical model of domination and subordination is not the issue we are addressing (Revizorski, 2015).

\subsection{The Development Dynamics of the International Political System}

Differences in approaches aimed at defining the main component of the system of international relations, from our perspective, tend to appear primarily due to the high transformation dynamics of the subject studied. The authors of each of the explanatory models tend to describe the same process, but at different stages of its development. Therefore, it is inevitable that pretty fast these concepts partially lose their relevance and, consequently, become less significant for the goals pursued (Kosolapov, 2005).

Moreover, it should be emphasized that the system of international relations is being transformed in fragments and a one-time transformation of its entire structure is hardly feasible. As a consequence, within each region and sub-region, depending on the specifics of the socio-economic model and political system, we observe a combination of actors representing different approaches to defining the main component of the international political system (Revizorski, 2015).

The interactions among the eclectic international political system elements are also undergoing substantial changes. During the "bipolarity" period (it should be remembered that the concept of "two centers of power" in effect ignored China, India and a number of other influential States), the relationships of subjects to international politics within each of the camps to a certain extent were built within the frame of vertical subordination. The latter was caused by the objective dominance of the Soviet Union and the United States in the military and economic spheres as well as by the presence of a serious external threat that forced the "Junior partners" to consolidate around Moscow and Washington, respectively (Osipov, 2018). There was a clash between the two world systems, that led to the Cold War. Then there was a need in developing norms to create a system of peaceful coexistence (Abramova, 2019).

However, the defeat of the Soviet Union in the Cold War significantly changed the international situation. With the common threat in the face of the USSR disappearance as a superpower, the dependence of the US allies from Washington became weaker (which was largely conditional even during the global confrontation - suffice it to recall the economic rivalry between the United States and Japan in the 1970s). Most of the states did not consider international terrorism to pose an acute enough threat for them to consolidate around the USA. Washington's habit to conclude situational alliances with extremists also played its part (suffice it to recall the interaction of the US forces and al-Qaeda in the Arabian Peninsula to counter the Houthis in Yemen). At the same time, the United States has not been able to develop a proper protection tool against the threat posed on its allies: the presence of an 
American military base on the state territory provokes rather than deters terrorists. On a global scale, soon there appeared counterweights to Washington's economic influence in the face of China, India, Brazil, the emerging European Union. In the 2000s, Russia returned to geopolitical arena. And although it did not have the potential of the USSR, the country's importance was too high for its opinion to be ignored. The rivalry between the renewed "centers of power" was dialectically accompanied by cooperation. Thus, China, being the main US competitor in the international economy, at the same time was extremely dependent on its opponent: it is the United States that remains the main sales market for China, and it is Beijing that is the largest holder of the US treasury debt obligations (Mosyakov, 2006). Therefore, there is a multi-polar world that requires a change in approaches and methods of managing international processes. It demands looking from another perspective at both the place and the role of the main UN bodies as well as the UN in general as a leading link in maintaining peace and international security (Ryzhov \& Shinkaretskaia, 2015).

The dialectical relationship between the main actors was determined by the developing economic globalization (Ryzhov, 2014). The international economic structures (GATT, WTO, World Bank, etc.) were established largely due to the "internationalization" of economic and political elites. The models of national economies being restructured for most developed countries in a neoliberal manner enshrined the trend within the power circles to abandon the promotion of national interests that were replaced by personal and corporate ones even to a larger extent than within the framework of the previous model. For large corporations success has become less dependent on the support of a strong nation-state. Meanwhile, the presence of the corporation's facilities owned by developed countries on the territory of the "metropolis" began to be considered as a source of losses associated with the need to comply with the local social and labor laws. It contributed to the massive transition towards overseas manufacturing. Changes in the business strategy naturally transformed political interests of the large-scale business. At the same time, there was evidence that the ties between political and economic establishment were strengthening. That resulted from a number of factors. Neoliberal reforms reduced the overall number of high-paying jobs, which led to a decrease in share of the middle class in total population. The increasing societal polarization strengthened the electoral role of both the most affluent strata (due to the increase in their resource base) and representatives of the lower social strata (due to the growth of their number). Thus, the representatives of the top of the social pyramid are of key importance. Politicians needed their assistance, which often entailed tacit agreements that included a certain range of obligations, for accumulating resources for electoral campaigns. Meanwhile, it was relatively easy to gain grassroots support. It was ensured by political populism combined with the absence of an obvious alternative. Most developed countries had a system of shift dominance of several major parties, that had broken away from their original social base and were taking centrist positions to the detriment of the "originaldeology. The combination of such factors as a decreasing interest of business in a strong national state, the "internationalization" of large companies, a decreasing political weight of the middle class against the growing importance of elites eventually gave rise to the trend of economic and political globalization (Melvil, 2004).

Therefore, up to the mid-2010s, the format of interaction between the main actors of the international political system was characterized by a complex interdependence. Given this, even serious reasons for conflicts (the US invasion of Iraq, the "color revolutions") were not converted into the full-scale confrontations. Arising contradictions were stopped by means of situational alliances that at least temporarily balanced interests of the parties involved (Tebekin, A.V., 2017).

However, with the beginning of the conflict in Ukraine, this system of interaction began to fail. And Donald Trump becoming the President of the United States and dismantling the agreement on the Transatlantic and the Trans-pacific partnerships and almost initiating trade wars with China and the EU jeopardized this model of communication. Actually, we are witnessing the developing tendency to abandon economic (and, as a consequence, political) globalization in favor of creating macro-regional enclaves built around a network of deeply integrated national markets. The latter was mainly related to the specifics of the socio-economic development of the leading countries of the international community. From one perspective, a number of developed countries faced a request to "roll back" the social consequences of neoliberal reforms, which implied at least partial cancellation of the results of economic and political globalization. From the other perspective, the globalization trajectory has begun to concern part of the establishment: those states elites they used to regard as Junior partners, began to enhance their economic capacity, gradually converting it into political influence. In the long-term perspective, this implied a change of positions among the elites of the leading countries of globalization. Thus, globalization could be transformed from a process of spreading the Western elites influence into a mechanism of their gradual subordination. The parallel growing discontent over the existing external economic policy (which also affects the domestic political situation) both within the establishment and the vast populations led to attempts to politically revise the existing system of international relations (Kovalev, 2017). 
This process was largely facilitated by the thinking inertia of the US political establishment. The F. Fukuyama concept of "the end of history" was taken literally by the majority of the American establishment. Although the representatives of the Bill Clinton administration (who raised the question of the transition from the strategy of global domination to the concept of global leadership) saw the early evidence of its failure, new world order realities have not been fully understood. It took the negative experience of the George Bush Jr. tenure to realize that the economic, political and image costs of trying to build a unipolar system are extremely high. The US invasion of Iraq and the subsequent occupation of the country, which unfolded in parallel with the campaign in Afghanistan, showed that even one local conflict, in case of transitioning into a protracted phase, can seriously affect the economy, undermine the authority of the United States in the international arena and lead to serious changes in the political life of America, eroding the popularity of the dominant party at that time (Osipov, 2018).

It should be stated that despite such events the United States did not completely abandon the ambitious projects to gain and maintain global leadership. Starting from implementing "soft power" to produce their values and norms on the citizens of foreign countries (Pliev \& Plieva, 2019) and ending up with supporting a number of coups and local wars in the middle East. Meanwhile, the main beneficiary of this regional "chaos" was not even the United States itself. The wave of "color revolutions" in the middle East, on one side, strengthened Washington's Junior partners - Qatar and Saudi Arabia, on the other side, boosted Iran's influence in the region. Using the Shiite provinces of Iraq as a springboard, this state almost established control over Bahrain, began to threaten the oil-bearing regions of Saudi Arabia (populated mainly by Shiites), expanded its presence in Yemen and Syria. In this context, the "nuclear deal" between the West and Iran almost jeopardized the strategic interests of the United States in the middle East (which largely explains the change of course towards Tehran after D. Trump came to power). Another example of the negative consequences of Washington's attempts to ensure its global dominance was the transition to direct confrontation with Russia after the escalation of the Ukrainian crisis. The Obama administration was well aware that the euroassociation of Ukraine or the overthrow of V.F. Yanukovych will not bring the USA strategic benefits. This was clearly indicated by the first Maidan: the victory of V.A. Yushchenko eventually did not give the United States a single advantage. It was clear that imposing sanctions against Russia would only lead to a protracted conflict with Moscow, which would hamper relationship-building with Russia if there was a need to solve issues crucial for the US (Valuev, 2016).

The conflicts generated by the thinking inertia of the US elites as a result, on the one hand, promoted destabilization of the mechanisms developed by leading actors that were designed to find compromises, and on the other hand - forced the USA to spend resources counter-productively, thus indirectly discrediting the Western (actually - American) globalization strategy (Pantin \& Lapkin, 2002).

The tendency to abandon the latter can be traced, as noted previously, within the part of the American establishment that is focused on supporting D. Trump. His foreign policy basically comes down to concentrating the efforts on several areas directly related to the economic interests of the United States. The attempts of the American leader to "force" partners to increase payments for the maintenance of the US military bases in this case have an ambivalent nature: on one side, they justify for the American public the reduction of the external military presence by stating that some partners refused to cooperate, and on the other side - they push "unprofitable" allies to reduce the scale of military cooperation with the United States ( Pantin \& Lapkin, 2002).

\section{Conclusions}

To conclude, it is obvious that if the American establishment continues the present foreign policy in the mid-term perspective, the mechanisms operated in the 1990s-early 2010s and designed to coordinate and balance the interests of the international politics leading actors will cease to work. The system of short-term situational alliances among the "great powers" will be replaced by a conglomerate of macro-regional units founded on the economic integration that might be either formally institutionalized or informal.

It is deemed impossible to determine the exact prospects for the transformation of the international policy system in the short-term perspective: this process is still in an active phase and is far from complete.

Indeed, to date, the structure of the international political system continues to change rapidly and remains unstable. We witness significant changes in the framework of its basic components as well as in the nature of the relationships among them. Therefore, it can be noted that the trend towards growing global integration and governance through the creation of short-term reactive alliances of leading actors for the relief of contradictions in the least conflictual manner is being replaced by the trend towards clustering groups of actors with the increasing level of confrontation between them. 


\section{References}

Abramova, O. K. (2019). Selected Aspects of the OSCE's Activities to Ensure European Security. Education and Law, 5, 11-17.

Ilyin, M. V. (2012). State Recognition in the Context of World System's Evolution. International Trends, 1(28), $18-27$.

Ivonina, O. I. (2017). The role of the UN in the new world order. Tomsk State University Journal, 417, 75-79. https://doi.org/10.17223/15617793/417/11

Kaverin, M. A., \& Malkov, S. Y. (2014). Develompent of international organisations in the context of evolution of global political system. Vestnik RUDN. International Relations, 2, 200-209.

Kosolapov, N. A. (2005). World Politics as Phenomenon and as Subject of Science (To the Discussion on the Pages of the Polis and the Mezhdunarodnyje Protzessy Journals). Polis. Political Studies, 6(90), 92-110. https://doi.org/10.17976/jpps/2005.06.06

Kovalev, A. A. (2017). Analysis of options for the formation of the international security system during the clash of civilizations. National Interests: Priorities and Security, 12(357), 2349-2362. https://doi.org/10.24891/ni.13.12.2349

Lantsov, S. A. (2018). Polycentricity of the international system as the basis for the formation of a new world political order. VIII Russian Congress of Political Science Development Policy, State and World Order, 302-303.

Melvil, A. Yu. (2004). Once More on Comparative Politics and World Politics. Polis. Political Studies, 5(82), 114-120. https://doi.org/10.17976/jpps/2004.05.12

Mosyakov, D. (2006). Modernization of socio-political systems as a source of international stability. Asia and Afrika today, 3(584), 20-23.

Osipov, A. V. (2018). Modern military and political conflicts in international relations. Scientific works of the Republican Institute of higher education, 17, 125-132.

Pantin, V. I., \& Lapkin, V. V. (2002). Evolutionary Complication of Political Systems: Problems of Methodology and Research. Polis. Political Studies, 2, 6-19.

Pliev, S. V., \& Plieva, A. M. (2019). State stability in the context of stability of the newly formed states of the post-soviet space. Education and Law, 8, 190-194.

Radyukova, Ya. Yu., Kulik, Yu. P., \& Pakhomov, N. N. (2015). Role and place of globalization processes in system of economic security. Social and Economic Phenomena and Processes, 8, 107-112.

Ramonova, M. A. (2011). Modern management concepts and strategies in world politics. Politics and society, $11(83), 80-90$.

Revizorski, M. (2015). G7/8 - G20 - BRICS: A New Triad in Global Governance? International Organisations Research Journal, 4, 29-48. https://doi.org/10.17323/1996-7845-2015-04-29

Rymkevich, V. V. (2018). Political risks in the system of international economic relations. Vestnik of the Belarusian state University of Economics, 4(129), 12-19.

Ryzhov, V. B. (2014). Integration as a trend in modern development. International Law and International Organizations, 2, 304-312. https://doi.org/10.7256/2226-6305.2014.2.11581

Ryzhov, V. B., \& Shinkaretskaia, G. G. (2015). World order: from World War II to present time. International Law and International Organizations, 4, 396-404. https://doi.org/10.7256/2226-6305.2015.4.16400

Seidov, Sh. G. (2008). Modern information and political systems and their influence on international relations. Law and policy, 6, 1407-1413.

Tebekin, A. V. (2017). To the question on the question on the analysis of international relations in the dynamics of development of regional socio-economic and political systems. Journal of Political Research, 3, 123-136.

Tsygankov, P. A. (2005). The Substance of World Politics as a Discipline. International Trends, 1(7), 35-47.

Valuev, A. V. (2016). Historical significance and political role Brexit in the evolution of the global system of international relations. Journal of scientific and applied research, 7, 83-88. 


\section{Copyrights}

Copyright for this article is retained by the author(s), with first publication rights granted to the journal.

This is an open-access article distributed under the terms and conditions of the Creative Commons Attribution license (http://creativecommons.org/licenses/by/4.0/). 